Jurnal InFestasi

Vol. 13 No. 1 Juni 2017

Hal. $297-308$

\title{
Kesalahan Mekanisme Pemungutan Pajak Pertambahan Nilai
}

\author{
Sri Hanggana 1 \\ ${ }^{1}$ Fak. Ekonomi dan Bisnis Universitas Sebelas Maret, Surakarta Jl Ir. Sutami No. 36 A Kentingan Surakarta 57126. \\ Telp 646994, 646624 Faks 646655
}

\section{Key words:}

Mistakes

Tax collection

Entrepreneuer

Customers

\section{A B S T R A C T}

The purpose of this study is to find the mistake of the PPN collection according to UU No. 42 th 2009 about alteration of UU No. 8 th 1983 about PPN and PPnMB. The mistake is caused the low of payment of PPN. Hanggana (2008) concluded that $97 \%$ businessmen choose manipulation strategy on PPN. Those mistakes are (1) pushing constumer to not pay PPN so the cost is lower, do not break the law, no punishment, and available in the same place, (2) customer who pay PPN can not control the flow of money to the government, (3) pushing the entrepreneuer not become a PKP in order to low the cost, (4) pushing entrepreneuer to take PPN without fee, but there is a punishment, jail and fine, (5) entrepreneuer need large capital to pay PPN in, (6) if all entrepreneuer are tax-abiding, then the small entrepreneuer and non-PKP entrepreneuer are passed the tax-abiding one's, (7) tax-abiding entrepreneuer because of high cost, (8) tax-abiding entrepreneuer become bangkrupt, (9) entrepreneuer who manipulate tax will be bangkrupt because of paying fine and jailed, (10) the existing entrepreneuers are they who manipulated tax, but not jailed, (11) entrepreneuer who manipulate PPN should manipulate PPh for earnings and wages.

\section{A B S T R A K}

Kajian ini bertujuan menemukan kesalahan mekanisme pemungutan PPN berdasarkan UU nomor 42 tahun 2009 tentang perubahan ketiga atas UU nomor 8 Tahun 1983 tentang PPN dan PPn BM. Kesalahan ini diduga menjadi penyebab rendahnya tingkat ketaatan pembayaran PPN. Hanggana (2008) menyimpulkan 97\% pengusaha memilih strategi memanipulasi PPN. Kesalahan mekanisme pemungutan PPN diantaranya: (1) mendorong konsumen tidak membayar PPN, karena harga lebih murah, tidak melanggar hukum, tidak ada sanksi, dan tersedia di lokasi yang sama. (2) Konsumen yang taat membayar PPN tidak dapat mengawasi, apakah uang PPN yang dititipkan ke pengusaha disetorkan ke negara atau tidak. (3) mendorong pengusaha tidak menjadi PKP, sehingga harga lebih murah. (4) menjadikan Pengusaha wajib pungut PPN tanpa imbalan, tapi ada sanksi penjara dan denda. (5) Pengusaha membutuhkan modal lebih besar untuk membayar PPN masukan.(6) Jika kondisi Pengusaha semua taat, maka munculnya Pengusaha Kecil dan Pengusaha Non-PKP akan mematikan usaha Pengusaha yang taat. (7) Pengusaha yang mentaati UU PPN bangkrut, karena harga lebih tinggi. (8) Jika kondisi Pengusaha banyak yang tidak taat, maka Pengusaha yang bertaubat ingin mentaati UU PPN akan bangkrut, karena harga lebih tinggi. (9) Pengusaha yang memanipulasi PPN bangkrut jika diproses sesuai hukum, karena tidak mampu membayar denda dan dipenjara. (10) Pengusaha yang hidup adalah yang memanipulasi PPN dan PPh, tetapi tidak diproses sesuai hukum (11) Pengusaha yang memanipulasi PPN, harus memanipulasi PPh laba perusahaan dan PPh karyawan.

\section{PENDAHULUAN}

Kajian ini dimotivasi dua hal. Pertama, sangat rendahnya ketaatan pengusaha membayar
PPN. Hanggana (2008) meneliti pengusaha yang beromset diatas Rp 3 milyar per tahun, yang seharusnya mereka menjadi PKP, karena batasan

* Corresponding author, email address: ${ }^{1}$ srihanggana@gmail.com 
PKP saat itu beromset Rp 600 juta per tahun, menemukan:

1. Responden yang mengaku memilih strategi memanipulasi PPN dan PPh 97\%, terdiri dari $30 \%$ tidak mendaftar menjadi PKP dan tidak menyetor PPN atau memanipulasi secara total, dan $67 \%$ mendaftar menjadi PKP dan menyetor PPN dan PPh yang dimanipulasi atau dibawah dari yang seharusnya. Hanya 3\% yang mengaku memilih strategi menjadi PKP dan mentaati PPN dan PPh. Pengusaha yang memanipulasi PPN, maka juga harus memanipulasi PPh karyawan dan PPh laba perusahaan.

2. Jika manipulasi PPN dan PPh diketahui, semua responden memilih strategi melobi, dan atau menyuap Aparat Pajak, sehingga tidak diproses sesuai hukum.

3. Responden saat membeli barang, semuanya memilih tanpa membayar PPN.

Temuan ini didukung pernyataan Kepala Sub Direktorat Peraturan PPN Perdagangan, Jasa dan Pajak Tidak Langsung Lainnya Direktorat Peraturan Perpajakan I DJP, Hestu YS(http://www.pajak.go.id/), memaparkan per April 2011,jumlah wajib pajak terdaftar 22 juta.Jumlah ini terdiri dari 19.881.684 wajib pajak orang pribadi dan 1.929.507 wajib pajak badan. Tahun 2011, Ditjen Pajak hanya mendapatkan laporan surat pemberitahuan (SPT) masa PPN dari 325.000 PKP atau 42\% dari 775.000 PKP.

Motivasi kajian kedua adalah masih sangat pentingnya penerimaan PPN dan PPh Non-Migas bagi APBN. Besarnya PPN mempengaruhi besarnya PPh Non-Migas, karena Pengusaha yang memanipulasi PPN, maka juga harus memanipulasi PPh karyawan dan PPh laba perusahaan. APBN 2015 menyebutkan total pendapatan negara Rp1.7943,6 trilyundengan perincian di tabel 1. PPh Non-migas memberikan Rp 555,7 trilyun atau 31\% dan merupakan penerimaan tertinggi, disusul PPN Rp 525 trilyun atau 29,3\% yang merupakan penerimaan tertinggi ke dua. Jumlah PPh Non-Migas dan PPN Rp1.080,7 trilyun atau $60 \%$ dari total pendapatan, sehingga menjadi sumber penerimaan terpenting bagi APBN. Dengan demikian diperlukan kajian untuk kesalahan mekanisme pemungutan PPN sebagai bahan memperbaiki model pemungutan PPN, sehingga tidak menimbulkan kekacauan pembiayaan pemerintah.

\section{Tabel 1}

Pendapatan Negara 2015 (dalam trilyun)

\begin{tabular}{|c|c|c|}
\hline Jenis & Jumlah & $0 / 0$ \\
\hline PPh Non- & & \\
\hline Migas & 555,7 & $31,0 \%$ \\
\hline PPN & 525,0 & $29,3 \%$ \\
\hline PNBP & 410,3 & $22,9 \%$ \\
\hline $\begin{array}{l}\text { Kepabeanan } \\
\text { dan Cukai }\end{array}$ & 178,3 & $9,9 \%$ \\
\hline PPh Migas & 88,7 & $4,9 \%$ \\
\hline PBB & 26,7 & $1,5 \%$ \\
\hline Pajak Lainnya & 5,7 & $0,3 \%$ \\
\hline $\begin{array}{l}\text { Penerimaan } \\
\text { hibah }\end{array}$ & 3,3 & $0,2 \%$ \\
\hline $\begin{array}{l}\text { Total } \\
\text { Penerimaan }\end{array}$ & $1.793,7$ & $100 \%$ \\
\hline
\end{tabular}

Dasar hukum pengenaan PPN adalah UU nomor 42 Tahun 2009, tentang perubahan ketiga atas UU nomor 8 Tahun 1983 tentang PajakPertambahan Nilai Barang dan Jasa dan Pajak Penjualan atas Barang Mewah, selanjutnya disebut UU PPN, karena dalam kajian hanya menyangkut PPN.Pasal 4 menyebutkan obyek PPN adalah: (1) Penyerahan BKP (Barang Kena Pajak) di dalam Daerah Pabean yang dilakukan oleh Pengusaha. (2) Impor BKP yang dilakukan oleh siapapun.(3) Penyerahan JKP (Jasa Kena Pajak) di dalam Daerah Pabean oleh Pengusaha.(4) Pemanfaatan BKP tidak berwujud dari luar Daerah Pabean di dalam Daerah Pabean.(5) Pemanfaatan JKP dari luar Daerah Pabean di dalam Daerah Pabean.(6) Ekspor BKP oleh PKP.

Subyek wajib PPN ada 2, yaitu Pembeli atau konsumen sebagai wajib bayar PPN, dan Pengusaha yang menyerahkan BKP dan atau JKP sebagai wajib pungut PPN. Pasal 1 ayat 15 mendefinisikan PKP adalah pengusaha yang melakukan penyerahan BKP dan atau penyerahan JKP yang dikenakan pajak berdasarkan UU ini, tidak termasuk Pengusaha Kecil yang batasanya ditetapkan dengan Keputusan Menteri Keuangan, kecuali Pengusaha Kecil yang memilihdikukuhkan sebagai PKP. Pasal 7 menyebutkan Tarif PPN adalah 10\%. Tarif PPN dapat diubah menjadi paling rendah $5 \%$ dan paling tinggi 15\% melalui Peraturan Pemerintah. 


\section{TEORI}

Pengertian dan Kewajiban PKP

Pengertian PKP dijelaskan di Peraturan

Menteri

Keuangan

nomor

197/PMK.03/2013tentang batasan pengusaha kecil

PPN.Pasal 1 menjelaskan, Pengusaha kecil adalah pengusaha yang selama satu tahun buku melakukan penyerahan BKP dan/atau JKP dengan jumlah peredaran bruto dan/atau penerimaan bruto tidak lebih dari Rp4.800.000.000(empat miliar delapan ratus juta rupiah). Pasal 2, Pengusaha kecil sebagaimana dimaksud dalam Pasal 1 ayat (1) tidak wajib melaporkan usahanya untuk dikukuhkan sebagai Pengusaha Kena Pajak dan tidak wajib memungut, menyetor, dan melaporkan PPN dan PPn BM atas penyerahan BKP dan/atau JKP yang dilakukannya. Pasal 4, Pengusaha wajib melaporkan usahanya untuk dikukuhkan sebagai PKP, apabila sampai dengan suatu bulan dalam tahun buku jumlah peredaran bruto dan/atau penerimaan brutonya melebihi $\mathrm{Rp} 4,8$ milyar. Kewajiban melaporkan usaha untuk dikukuhkan sebagai Pengusaha Kena Pajak dilakukan paling lama akhir bulan berikutnya setelah bulan saat jumlah peredaran bruto dan/atau penerimaan brutonya melebihi Rp4,8 milyar. Pasal 5, apabila diperoleh data dan/atau informasi yang menunjukkan adanya kewajiban perpajakan sebagaimana dimaksud dalam Pasal 4 ayat tidak dipenuhi pengusaha, Direktur Jenderal Pajak dapat mengukuhkan pengusaha sebagai PKP secara jabatan.

Model Pemungutan PPN Berdasarkan UU PPN 42 Tahun 2009

Model pemungutan PPN berdasarkan UU 42 tahun 2009 secara operasional diatur lebih lanjut dengan Permenkeu. Permenkeu nomor 197/PMK.03/2013pasal 6 menyebutkan, Pengusaha yang sudah menjadi PKP mempunyai kewajiban yang berkaitan PPN diantaranya:

1. PKP membayar PPN ke Suplier yang sudah PKP saat membeli, dan minta faktur pajak sebagai bukti telah membayar PPN, bukti ini disebut PPN masukan.

2. PKP memungut PPN dari pembeli/custumer saat menjual BKP dan atau JKP.

3. PKP membuat faktur pajak sebagai bukti pungut PPN, dan disebut PPN keluaran.

4. PKP membuat pembukuan dan SPT (surat pemberitahuan) PPN.

5. PKP Menyetorkan SPT yang merupakan rekapan PPN keluaran dan PPN masukan, dan menyetorkan PPN yang kurang dibayar ke Kantor Pajak

\section{Model Pemungutan PPN Tidak Memenuhi Syarat} Keadilan dan Ekonomis

Pembuatan undang-undang dan peraturan harus memenuhi syarat keadilandan syarat ekonomis.Pemungutan pajak harus adil, yaitu dikenakan kepada orang sebanding dengan kemampuan untuk membayar pajak tersebut. Wajib pajak yang mempunyai kemampuan membayar yang sama harus dikenakan pajak yang sama (keadilan horizontal). Dan wajib pajak yang mempunyai kemampuan membayar yang tidak sama harus dikenakan pajak yang tidak sama (keadilan vertikal). Adanya klasifikasi PKP dan Pengusaha Kecil Non PKP menyebabkan Pembeli sebagai wajib bayar PPN memiliki alternatif tidak membayar PPN secara legal, yaitu membeli BKP dan JKP ke Pengusaha Kecil Non PKP atau ke Pengusaha Besar yang terpaksa belum PKP.Klasifikasi PKP dan Non PKP salah alamat, karena kewajiban membayar PPN berada pada Pengkonsumsi (Pembeli) bukan Penjual, sehingga UU PPN tidak memenuhi syarat keadilan. Ada dua bukti tidak dipenuhinya syarat keadilan. Pertama, Pembeli sebagai wajib bayar PPN dapat membayar pajak yang berbeda, karena membeli di tempat yang berbeda. Jika Konsumen membeli di PKP maka dia membayar PPN 10\%, tapi jika membeli ke Non PKP, maka konsumen tidak membayar PPN.Kedua, Pembeli yang tidak melaksanakan kewajiban membayar PPN tidak mendapatkan sangsi dan dianggap mengambil tindakan yang cerdas, sedangkan PKP yang tidak melaksanakan kewajiban memungut PPN diberikan sanksi.Sanksi tersebut yaitu: (1) Membayar PPN yang gagal dipungut dari Pembeli, atau dengan kata lain, PKP menyetor PPN ke Kantor Pajak dengan uangnya sendiri, bukan dari uang yang dipungut dari pembeli. (2) Membayar denda 2 sampai 6 kali lipat PPN terutang dan pidana 2 sampai 6 tahun sesuai UU KUTC (Ketentuan Umum dan Tata Cara Perpajakan) pasal 39 A.

UU PPN dan PPn BM juga tidak memenuhi syarat ekonomis.Syarat ekonomis menghendaki pembayaran pajak harus menjaga keseimbangan kehidupan ekonomi, dan jangan sampai mengganggu kehidupan ekonomis dari wajib pajak. PPN merupakan pajak tidak langsung, artinya kewajiban membayar pajak bisa digeserkan kepada orang lain. PKP yang menyerahkan BKP atau JKP mempunyai kewajiban memungut PPN dan menyetorkan ke Kantor Pelayanan Pajak, dan tidak berkewajiban membayar PPN.Sedangkan Pembelimempunyai kewajiban membayar PPN.Dalam menjalankan usahanya, ternyata PKP 
kesulitan memungut PPN dari Pembeli.Dalam kondisi ini PKP menghadapi 2 pilihan yang sangat merugikan dirinya, dan dua-duanya bisa membunuh usaha yang dijalankan. Pengusaha yang mentaati UU PPN dengan memungut PPN dari pembeli akan bangkrut, karena ditinggal pembeli sebagai akibat harga yang lebih mahal. Sedangkan Pengusaha yang melanggar UU PPN akan bangkrut juga, karena terkena denda 2 sampai 6 kali PPN yang gagal dipungut dan pidana penjara 2 sampai 6 tahun.Inilah bukti UU PPN tidak memenuhi syarat ekonomis, karena PKP sebagai wajib pungut PPN dapat mati usahanya jika mematuhi maupun melanggar UU PPN.

\section{Pajak Penghasilan}

UU no. 3 tahun 2008 tentang perubahan keempat atas UU no. 7 tahun 1983 tentang pajak penghasilan, pasal 4 menyebutkan yang menjadi objek pajak adalah penghasilan, yaitu setiap tambahan kemampuan ekonomis yang diterima atau diperoleh Wajib Pajak, baik yang berasal dari Indonesia maupun dari luar Indonesia, yang dapat dipakai untuk konsumsi atau untuk menambah kekayaan Wajib Pajak yang bersangkutan, dengan nama dan dalam bentuk apa pun. Dengan demikian laba usaha dan gaji karyawan juga termasuk obyek PPh.Perhitungan laba usaha sangat dipengaruhi penjualan yang menjadi dasar pengenaan PPN.Pasal 17 menyebutkan tarif PPhWajib Pajak badan dalam negeri dan bentukusaha tetap 25\% yang mulaiberlaku sejak tahun pajak 2010. Sedangkan tarif wajib pajak pribadi 5\% untuk penghasilan kurang dari Rp50 juta, $15 \%$ untuk penghasilan Rp 50 juta sampai Rp 250 juta, 25\% untuk penghasilan Rp250 juta samapi Rp 500 juta, dan 30\% untuk penghasilan diatas Rp 500 juta per tahun.

\section{Pelanggaran dan Sanksi}

UU nomor 28 tahun 2007 tentang Ketentuan Umum dan Tata Cara Perpajakan menyebutkan terdapat beberapa pasal yang memberikan sanksi atas pelanggaran yang dilakukan wajib pajak, aparat pajak, maupun pihak lain yang terlibat dalam pelanggaran pajak. Pasal 38, setiap orang yang karena kealpaannya:

a. Tidak menyampaikan Surat Pemberitahuan.

b. Menyampaikan Surat Pemberitahuan, tetapi isinya tidak benar atau tidak lengkap, atau melampirkan keterangan yang isinya tidak benar sehingga dapat menimbulkan kerugian pada pendapatan Negara.

Atas pelanggaran tersebut didenda paling sedikit 1 (satu) kali dan paling banyak 2 (dua) kali jumlah pajak terutang yang tidak atau kurang dibayar, atau dipidana kurungan paling singkat 3 (tiga) bulan atau paling lama 1 (satu) tahun.

Pasal 39 (1) menyatakan, setiap orang yang dengan sengaja:

a. Tidak mendaftarkan diri untuk diberikan Nomor Pokok Wajib Pajak, atau tidak melaporkan usahanya untuk dikukuhkan sebagai Pengusaha Kena Pajak.

b. Menyalahgunakan atau menggunakan tanpa hak Nomor Pokok Wajib Pajak atau Pengukuhan Pengusaha Kena Pajak.

c. Tidak menyampaikan Surat Pemberitahuan.

d. Menyampaikan Surat Pemberitahuan dan/atau keterangan yang isinya tidak benar atau tidak lengkap.

e. Menolak untuk dilakukan pemeriksaan sebagaimana dimaksud dalam Pasal 29.

f. Memperlihatkan pembukuan, pencatatan, atau dokumen lain yang palsu atau dipalsukan seolaholah benar, atau tidak menggambarkan keadaan yang sebenarnya.

g. Tidak menyelenggarakan pembukuan atau pencatatan di Indonesia, tidak memperlihatkan atau tidak meminjamkan buku, catatan, atau dokumen lain.

h. Tidak menyimpan buku, catatan, atau dokumen yang menjadi dasar pembukuan atau pencatatan dan dokumen lain termasuk hasil pengolahan data dari pembukuan yang dikelola secara elektronik atau diselenggarakan secara program aplikasi online di Indonesia sebagaimana dimaksud dalam Pasal 28 ayat (11).

i. Tidak menyetorkan pajak yang telah dipotong atau dipungut sehingga dapat menimbulkan kerugian pada pendapatan Negara.

Atas pelanggaran tersebut dipidana dengan pidana penjara paling singkat 6 (enam) bulan dan paling lama 6 (enam) tahun dan denda paling sedikit 2 (dua) kali dan paling banyak 4 (empat) kali jumlah pajak terutang yang tidak atau kurang dibayar.

Pasal 39A, menyatakan setiap orang yang dengan sengaja:

a. Menerbitkan dan/atau menggunakan faktur pajak, bukti pemungutan pajak, bukti pemotongan pajak, dan/atau bukti setoran pajak yang tidak berdasarkan transaksi yang sebenarnya.

b. Menerbitkan faktur pajak tetapi belum dikukuhkan sebagai Pengusaha Kena Pajak.

Atas pelanggaran tersebut dipidana dengan pidana penjara paling singkat 2 (dua) tahun dan paling lama 6 (enam) tahun serta denda 
paling sedikit 2 (dua) dan paling banyak 6 (enam) kali jumlah pajak dalam faktur pajak, bukti pemungutan pajak, bukti pemotongan pajak, dan/atau bukti setoran pajak.

Pasal 41 (1) menyatakan, Pejabat yang karena kealpaanya tidak memenuhi kewajiban merahasiakan hal sebagaimana dimaksud dalam Pasal 34 dipidana dengan pidana kurungan paling lama 1 (satu) tahun dan denda paling banyak Rp25 juta. (2) Pejabat yang dengan sengaja tidak memenuhi kewajibannya atau seseorang yang menyebabkan tidak dipenuhinya kewajiban pejabat sebagaimana dimaksud dalam Pasal 34 dipidana dengan pidana penjara paling lama 2 (dua) tahun dan denda paling banyak Rp50 juta. (3) Penuntutan terhadap tindak pidana sebagaimana dimaksud pada ayat (1) dan ayat (2) hanya dilakukan atas pengaduan orang yang kerahasiaannya dilanggar

Pasal 43 (1), menyatakan ketentuan sebagaimana dimaksud dalam Pasal 39 dan Pasal 39A, berlaku juga bagi wakil, kuasa, pegawai dari Wajib Pajak, atau pihak lain yang menyuruh melakukan, yang turut serta melakukan, yang menganjurkan, atau yang membantu melakukan tindak pidana di bidang perpajakan. (2) Ketentuan sebagaimana dimaksud dalam Pasal 41 berlaku juga bagi yang menyuruh melakukan, yang menganjurkan, atau yang membantumelakukan tindak pidana di bidang perpajakan.

Pasal 43A (1), menyatakan Direktur Jenderal Pajak berdasarkan informasi, data, laporan, dan pengaduan berwenang melakukan pemeriksaan bukti permulaan sebelum dilakukan penyidikan tindak pidana di bidang perpajakan. (2) Dalam hal terdapat indikasi tindak pidana di bidang perpajakan yang menyangkut petugas Direktorat Jenderal Pajak, Menteri Keuangan dapat menugasi unit pemeriksa internal di lingkungan Departemen Keuangan untuk melakukan pemeriksaan bukti permulaan. (3) Apabila dari bukti permulaan ditemukan unsur tindak pidana korupsi, pegawai Direktorat Jenderal Pajak yang tersangkut wajib diproses menurut ketentuan hukum Tindak Pidana Korupsi. (4) Tata cara pemeriksaan bukti permulaan tindak pidana di bidang perpajakan sebagaimana dimaksud pada ayat (1) dan ayat (2) diatur dengan atau berdasarkan Peraturan Menteri Keuangan.

\section{METODE PENELITIAN}

Kajian ini dilakukan dengan simulasi angka.Pemakaian angka hanya untuk mengambil kesimpulan dan memudahkan perbandingan.Hasil yang diperoleh tidak dibaca sebagai angka mutlak, tetapi dibaca secara kualitatif.

\section{HASIL DAN PEMBAHASAN \\ Simulasi Mekanisme Pemungutan PPN Sesuai UU PPN}

PPN dikenakan setiap kali terjadi penyerahan, sehingga besar kecilnya PPN yang diterima Negara juga dipengaruhi rentang saluran distribusi suatu barang.Semakin panjang saluran distribusi, semakin besar PPN, karena semakin banyak frekwensi penyerahan barang. Terdapat banyak ragam saluran distribusi dari produsen, pedagang, sampai ke konsumen akhir diantaranya: a. Produsen Tk (Tingkat) $1 \rightarrow$ KA (Konsumen Akhir)

b. Produsen Tk $1 \rightarrow$ Pedagang TK $1 \rightarrow \mathrm{KA}$

c. Produsen TK $1 \rightarrow$ Pedagang Tk $1 \rightarrow$ Pedagang Tk $2 \rightarrow \mathrm{KA}$

d. Produsen Tk $1 \rightarrow$ Produsen Tk $2 \rightarrow$ Pedagang Tk $1 \rightarrow$ Pedagang Tk $2 \rightarrow$ KA

Produsen adalah orang atau badan yang mengolah bahan baku menjadi barang jadi. Produsen tingkat satu adalah produsen yang mengolah bahan baku yang langsung diambil dari alam. Contoh, pabrik tepung tapioka yang mengolah bahan baku berupa ketela pohon yang diambil langsung dari alam. Produsen tingkat 2 adalah produsen yang mengolah bahan baku yang dibeli dari produsen tingkat 1 . Contoh, pabrik krupuk udang yang menggunakan bahan baku tepung tapioka yang dihasilkan pabrik tepung tapioka. Produsen tingkat 3 adalah produsen yang mengolah bahan baku yang dibeli dari produsen tingkat 2.

Pedagang adalah orang atau badan yang membeli barang dan menjual barang tersebut tanpa melakukan proses produksi. Spesifikasi barang yang dibeli sama dengan barang yang dijual. Pedagang tingkat 1 adalah pedagang yang membeli barang langsung ke produsen.Contoh, grosir krupuk udang yang membeli krupuk udang ke pabrik krupuk udang.Pedagang tingkat 2 adalah pedagang yang membeli barang dari pedagang tingkat satu.Contoh toko snak yang membeli krupuk udang dari grosir krupuk udang.Pedagang tingkat 3 adalah pedagang yang membeli barang dari pedagang tingkat 2.Semakin besar tingkatan pedagang, maka harga semakin mahal, distribusi semakin panjang, dan umumnya semakin kecil omset penjualannya.

Simulasi model pemungutan PPN atas transaksi penjualan dari Pedagang tingkat 2 ke Konsumen akhir yang taat PPN seperti yang diharapkan Pemerintah dapat dilihat di tabel 
2.Pedagang tingkat 2, yaitu Toko menjual krupuk udang ke KA (Konsumen Akhir).Kosumen akhir adalah orang yang mengkonsumsi langsung krupuk udangtersebut di wilayah Republik Indonesia.Misalkan di suatu pasar terdapat 3 Toko dan 3 Konsumen Akhir. Toko D memiliki omset penjualan Rp 4 milyar per tahun, sehingga masih berstatus PKC. Sedangkan Toko 1, dan 2 memiliki omset penjualan Rp 6 milyar per tahun, sehingga berstatus PKP. Toko PKC D membeli dari Grosir PKC; Grosir membeli dari Pabrik krupuk PKC.Toko PKP 1 membeli dari Grosir PKP; Grosir membeli dari Pabrik krupuk PKP. Toko menjual krupuk udang kualitas yang sama dengan harga per Kg Rp150. Toko berfungsi sebagai pedagang, penjual, dan sebagai wajib pungut PPN. Sedangkan Konsumen Akhir berfungsi sebagai pembeli dan wajib bayar PPN. Toko PKC D mempunyai langganan Konsumen KA D; Toko PKP 1 memiliki langganan Konsumen KA 1; Toko PKP 2 memiliki langganan Konsumen KA 2; Konsumen KA D sebagai pembeli hanya mengeluarkan uang Rp 150 per kg, karena membeli ke Toko D yang masih PKC, sehingga tidak dipungut PPN. Sedangkan Konsumen KA 1 dan KA 2 sebagai Pembeli membayar harga beli per Kg Rp 150 ditambah membayar PPN Rp15, sehingga uang yang dikeluarkan Rp 165 per Kg, karena membeli ke Toko yang sudah PKP (Baris 10, Kolom C, D, dan E). Dalam hal ini Toko secara riil tidak membayar PPN, karena PPN masukan Rp 12 yang sudah dibayarkan saat membeli ke Grosir diganti oleh Konsumen Akhir PPN keluran Rp 15, sehingga Toko mempunyai kewajiban menyetorkan kurang bayar PPN Rp 3 per $\mathrm{kg}$ ke Pemerintah. Jika Grosir, toko, dan Konsumen Akhir mentaati UU PPN, maka secara kumulatif pemerintah mendapatkan PPN Rp 15 per kg.

\section{Tabel 2}

\section{Simulasi Perhitungan PPN sesuai UU PPN}

\begin{tabular}{|r|l|c|r|r|}
\hline Brs & Penjual/ Pedagang Tk 2/Pemungut PPN & \multicolumn{3}{|c|}{ TOKO Krupuk Udang } \\
\hline 1 & Penjualan tanpa PPN per tahun (jutaan Rp) & 4.000 & 6.000 & 6.000 \\
\hline 2 & Status berdasarkan Omset Penjualan & PKC D & PKP 1 & PKP 2 \\
\hline 3 & sikap terhadap UU PPN & Taat & Taat & Taat \\
\hline 4 & Perhitungan per unit: & & & \\
\hline 5 & Harga Pokok Pembelian & 120 & 120 & 120 \\
\hline 6 & PPN masukan & 12 & 12 & 12 \\
\hline 7 & Jumlan Uang diserahkan ke Suplier & 132 & 132 & 132 \\
\hline 8 & Harga Jual & 162 & 150 & 150 \\
\hline 9 & PPN Keluaran & 0 & 15 & 15 \\
\hline 10 & Harga yang dibayar Pembeli/konsumen & 162 & 165 & 165 \\
\hline 11 & PPN kurang bayar & 0 & 3 & 3 \\
\hline 12 & Laba Kotor & 30 & 30 & 30 \\
\hline 13 & Kelangsungan hidup toko & Hidup & Mati & Mati \\
\hline 14 & Penyebab & H. Mrh & H. Mhl & H. Mhl \\
\hline
\end{tabular}

Kesalahan pertama mekanisme pemungutan PPN sesuai UU PPN yang ditemukan adalah secara alamiah mendorong konsumen sebagai wajib bayar PPN tidak membayar PPN, karena harga lebih murah, tidak melanggar hukum, tidak ada sanksi, dan tersedia di lokasi yang sama. KA 1 dan KA 2 yang selama ini membayar PPN akan termotivasi secara alamiah berpindah membeli ke PKC D, sehingga hanya membayar Rp 150, bukan Rp 165 per kg. Toko PKP 1 dan 2 tidak dapat memaksa KA 1 dan 2 untuk membeli dengan membayar PPN.Hanya pengusaha yang menjual barang secara monopoli, atau yang unik, yang tidak dijual di tempat lain, atau yang diregister Negara seperti mobil baru, yang dapat memaksa konsumen membayar PPN. Sri Hanggana (2006), menemukan $100 \%$ responden memilih membeli tanpa membayar PPN.Dalam simulasi diatas, konsumen akhir membayar PPN Rp 15, dan diterima pemerintah dua kali yaitu, Rp 12 dari grosir dan Rp3 dari toko. Kelemahan lainnya, PKP membutuhkan modal kerja lebih banyak untuk membayar PPN masukan saat membeli barang. Dalam kasus diatas, PKP membutuhkan tambahan modal kerja Rp 12/kg untuk mendapatkan barang $\mathrm{Rp} 120 / \mathrm{kg}$.

Kesalahan kedua, konsumen yang taat membayar PPN baik karena ketidakpahaman maupun keterpaksaan, tidak dapat mengawasi pengusaha, apakah uang PPN yang dititipkan ke pengusaha disetorkan ke negara atau tidak, karena tidak ada bukti. Konsumen KA 1 yang membeli di PKP 1 dan membayar PPN Rp 15 tidak dapat mengawasi apakah PKP 1 menyetorkan ke Kantor Pajak, sehingga melemahkan motivasi konsumen membayar PPN, karena takut tidak disetorkan ke Kantor Pajak.

Kesalahanketiga, mekanisme pemungutan PPN yang ditemukan adalah secara alamiah mendorong pengusaha tidak menjadi PKP. Dengan tidak menjadi PKP maka tidak dibebani kewajiban memungut PPN dari konsumen, maka dapat menjual dengan harga yang lebih murah, sehingga dapat memenangkan persaingan. Semakin besar batasan omset PKP, semakin mendorong pengusaha enggan menjadi PKP.

Kesalahan keempat mekanisme pemungutan PPN adalah mendzolimi Pengusaha, karena menjadikan Pengusaha wajib pungut PPN tanpa imbalan, tapi ada sanksi penjara dan denda. Kedzoliman ini akan memaksa pengusaha melakukana kejahatan pajak. Kedzoliman ini diperparah dengan kesalahan kelima, yaitu Pengusaha membutuhkan modal kerja lebih besar 
untuk membayar PPN masukan.

Simulasi Saat Kondisi Pengusaha Semua Taat, maka Munculnya Pengusaha yang Nakal dan Pengusaha Kecil akan Mematikan Usaha Pengusaha yang Taat

Misalkan, simulasi tabel 1 diatas, PKC D hanya mempunyai barang yang sedikit, sehingga tidak mampu memenuhi kebutuhan konsumen lain yang bukan custumernya, maka KA 1 dan KA 2 terpaksa masih membeli ke PKP 1 dan PKP 2. Kemudian pemilik Toko PKP 1 mendapatkan ide untuk memperbesar tokonya dan ingin mengalahkan Toko PKP 2, maka dia mendirikan toko lain atas nama isteri, anak, famili, atau teman yang dimulai dari omset yang kecil. Toko PKP 1 menyadari, bahwa harga merupakan senjata ampuh untuk memenangkan persaingan. Akibatnya, dari inisiatif dan ide Toko PKP 1 tersebut muncul banyak toko yang berstatus PKC, disamping itu juga tumbuh Toko PKC yang diciptakan investor lain yang tidak dikenal PKP 1. Beberapa toko baru yang pada awalnya PKC, berkembang pesat menjadi besar. Toko PKP 1 tidak dapat memaksa pemilik toko-toko baru yang bukan kelompoknya, yang sudah beromset lebih dari Rp 4,8 milyar per tahun harus menjadi PKP. Akibatnya, konsumen memiliki alternatif tempat pembelian yang banyak yang tidak memungut PPN, sehingga mengancam kelangsungan hidup Toko PKP 1 dan PKP 2 yang terlanjur menjadi PKP. Pemilik Toko PKP 1 kalaupun harus menutup Toko, dia sudah memiliki toko lain yang dapat beroperasi tanpa memungut PPN. Simulasi analisa kelangsungan hidup PKP yang taat saat munculnya PKC dan NPKP terdapat di tabel 2. PKP 1 dan PKP 2 seorang yang jujur dan beraklak mulia, dia justru memberitahu pada custumernya, jika ingin membeli tanpa membayar PPN maka disarankan ke toko D, E, 5, dan 6. PKP 1 dan PKP 2 juga tidak memaksa pemilik toko lainnya untuk taat memungut PPN. Wajib Pungut PPN yang konsisten mentaati UU PPN, dalam kasus ini Toko PKP 1 dan 2 dapat mengalami kebangkrutan usaha karena konsumen akhir KA 1 dan KA 2 mendapatkan banyak tempat membeli barang yang tidak memungut PPN.

Berdasarkan tabel 3, dapat disimpulkan, mekanisme PPN sesuai UU PPN mempunyai kesalahan keeanam, jika kondisi Pengusaha semua taat, maka munculnya Pengusaha Kecil dan Pengusaha NPKP akan mematikan usaha Pengusaha yang taat. Kebangkrutan usaha ini disebabkan ditinggal konsumen, akibat harga lebih tinggi. NPKP (Non PKP) adalah Pengusaha nakal yang beromset diatas $R p$ 4,8 milyar per tahun, tetapi tidak menjadi PKP. Kesalahan ketujuh, Pengusaha yang mentaati UU PPN bangkrut, karena ditinggal konsumen sebagai akibat harga jual yang lebih tinggi. PKP 1 dan PKP 2 mati karena menjual dengan harga lebih tinggi dibanding pengusaha lainnya.

\section{Tabel 3}

Simulasi Analisis Kelangsungan Hidup Bisnis Pengusaha yang Taat pada Saat Muncul Pengusaha yang Tidak Taat UU PPN

\begin{tabular}{|c|c|c|c|c|c|c|}
\hline Brs Peniual Pedagang TK2Pemunout PPN & \multicolumn{5}{|c|}{ TOKOKrupuk Udang } & \multirow[b]{2}{*}{6.000} \\
\hline 1 Penivalan tanpa PPN per tahun (utiaan Ro) & 4.000 & 6.000 & 6.000 & 4.000 & 6.000 & \\
\hline 2 Status berdasarkan Omset Peniualan & PKCD & PKP 1 & PKP2 & PKCE & NPKP 5 & NPKP $G$ \\
\hline 3 sikap termadaa UUPPPN & Taat & Taat & Taat & Taat & Tok taat| & Tok taal \\
\hline 4 Perhitungan per unit: & & & & & & \\
\hline 5 Harga Pokok Pembelian & 120 & 120 & 120 & 120 & 120 & 120 \\
\hline 6 PPN masukan & 12 & 12 & 12 & 0 & 0 & 0 \\
\hline 7 Jumlan Uang diseraakkanke Suplier & 132 & 132 & 132 & 120 & 120 & 120 \\
\hline 8 Harga Jual & 162 & 150 & 150 & 150 & 150 & 150 \\
\hline gPPN Keluaran & 0 & 15 & 15 & 0 & 0 & 0 \\
\hline 10 Harga yang dibayar Pembelikonsumen & 162 & 165 & 165 & 150 & 150 & 150 \\
\hline 11 PPN Kurang bayar & 0 & 3 & 3 & 0 & 0 & 0 \\
\hline 12 Laba Kotor & 30 & 30 & 30 & 30 & 30 & 30 \\
\hline 13 Kelangsungann hidup toko & Hidup & Maail & Mati & Hidup & Hidup & Hidup \\
\hline 14 Penyebab & H. Min & & $\mathrm{H}, \mathrm{Mh}$ & H. Mrh & H.Mrh & H.Mrh \\
\hline
\end{tabular}

Simulasi Saat Kondisi Pengusaha Semua Tidak Taat, maka Pengusaha yang Bertobat akan Bangkrut

Misalkan dari tabel 3 diatas, setelah PKP 1 dan 2 bangkrut, dua tahun kemudian PKC D dan E sudah beromset Rp 7 milyar per tahun, tetapi tidak mendaftar menjadi PKP, sehingga pada tahun tersebut terdapat 4 toko semua NPKP. Kemudian toko NPKP 6 bertaubat, mendaftar menjadi PKP 6. Setelah menjadi PKP 6, maka membayar PPN masukan saat membeli, dan memungut PPN keluaran saat menjual, dan menyetor PPN kurang bayar ke kantor pajak. PKP 6 orang yang jujur dan beraklak mulia, dia memberitahu pada custumernya, bahwa dia bertobat, dan akan memungut PPN saat menjual. Dia menyarankan jika custumernya ingin membeli tanpa membayar PPN, maka disuruh membeli ke toko NPKP D, NPKP E, dan NPKP 5. Simulasi analisa kelangsungan hidup PKP yang bertobat saat pengusaha lain banyak yang tidak taat terdapat di tabel 4. Kesimpulannya, mekanisme PPN sesuai UU PPN mempunyai kesalahan kedelapan, yaitu jika kondisi Pengusaha banyak yang tidak taat, 
maka Pengusaha yang bertaubat ingin mentaati UU PPN akan bangkrut, karena ditinggal konsumen, karena harga lebih tinggi.

\section{Tabel 4}

Simulasi Analisis Kelangsungan Hidup Bisnis Pengusaha yang Bertaubat Saat Pengusaha Lain Belum Bertaubat

\begin{tabular}{|c|c|c|c|c|}
\hline Brs Penjual/ Pedagang Tk 2/Pemungut PPN & \multicolumn{4}{|c|}{ TOK0 Krupuk Udang } \\
\hline 1 Penjualan per tahun dalam jutaan $\mathrm{Rp}$ & 7.000 & 7.000 & 6.000 & 6.000 \\
\hline 2 Status berdasarkan Omset Penjualan & NPKPD & NPKP E & NPKP 5 & NPKP 6 \\
\hline 3 sikap terhadap UUPPN & Tdk taat & Tdk taat & Tdk taat & TaatTobat \\
\hline 4 Perhitungan per unit: & & & & \\
\hline 5 Harga Pokok Pembelian & 120 & 120 & 120 & 120 \\
\hline 6 PPN masukan & 0 & 0 & 0 & 12 \\
\hline 7 Jumlah Uang diserahkan ke Penjual & 120 & 120 & 120 & 132 \\
\hline 8 Harga Jual & 150 & 150 & 150 & 150 \\
\hline 9 PPN Keluaran & 0 & 0 & 0 & 15 \\
\hline 10 Harga yang dibayar Pembeli & 150 & 150 & 150 & 165 \\
\hline 11 PPN kurang bayar & 0 & 0 & 0 & \\
\hline 12 Laba Kotor & 30 & 30 & 30 & 30 \\
\hline 13 Kelangsungan hidup toko & Hidup & Hidup & Hidup & Bangkrut \\
\hline 14 Pembeli/Konsumen/Pembayar PPN & KAD & $\mathrm{KAE}$ & KA 5 & KA 6 \\
\hline
\end{tabular}

\section{Simulasi Manipulasi PPN dan PPh yang Diduga Dilakukan Pengusaha}

Asumsi yang digunakan dalam simulasi ini:

1. Pengusaha memiliki toko krupuk udang PT. Slameto, bertindak sebagai penjual dan pemungut PPN saat menjual barang.

2. Omset penjualan sesungguhnya Rp 10 milyar per tahun

3. $\mathrm{PPh}$ yang digunakan $\mathrm{PPh}$ badan dengan tarif 25\% (Psl 17 ayat 2a UU 36 tahun 2008)

4. PPh karyawan $1 \%$, karena ada karyawan bergaji dibawah PTKP tidak dikenakan PPh, ada yang dikenakan tarif PPh $5 \%, 15 \%, 25 \%$, dan 30\%.

5. Nilai penjualan sebagai angka dasar atau $100 \%$, harga pokok pembelian barang dagangan $80 \%$ dari penjualan, biaya adsminitrasi-pemasaranbunga $6 \%$ dari penjualan, biaya gaji karyawan $5 \%$ dari penjualan, dan laba kotor 9\% dari penjualan.

6. Simulasi dalam manipulasi dilakukan proporsional agar mudah perhitungannya, misalkan, melakukan manipulasi dengan melaporkan penjualan sebesar 5\% dari penjualan sesungguhnya, maka biaya, dan laba juga dilaporkan $5 \%$, sehingga laporan laba rugi kelihatan wajar. Jika Penjualan dilaporkan Rp 500 juta, biaya gaji karyawan dilaporkan sesuai kenyataan Rp 400 juta, dan laba sesuai kenyataan Rp1,120 milyar, akan nampak tidak wajar.

Tabel 5 menggambarkan simulasi pilihan toko krupuk udang PT Slameto dan pengusaha lainnya dalam menghadapi UU PPN. UU PPN menghendaki PT Slameto melaporkan penjualan Rp10 milyar sesuai kenyataannya, membayar PPN masukan saat membeli barang dagangan Rp 800 juta, memungut PPN keluaran saat penjualan Rp 1 milyar, dan menyetorkan PPN kurang bayar Rp 200 juta ke Kantor Pajak. PT. Slameto secara riil tidak membayar PPN, hanya menalangi Rp 800 juta saat membeli barang dagangan, dan mendapatkan ganti $\mathrm{Rp} 1$ milyar dari custumer saat menjual. Sebagai penjual, PT. Slameto hanya wajib bayar $\mathrm{PPh}$ laba perusahaan Rp 280 juta, yaitu tarif PPh $25 \%$ dari laba Rp 1,120 milyar. Dari hasil simulasi diatas, jika PT. Slameto memilih mentaati UU PPN, maka dia akan bangkrut, karena ditinggalkan custumer sebagai akibat harga jual 10\% lebih tinggi.

Berdasarkan tabel 5 diketahui kesalahan kesembilan mekanisme pemungutan PPNyaitu,Pengusaha terpaksa memanipulasi PPN dan akan bangkrut jika diproses sesuai hukum, karena tidak mampu membayar denda dan dipenjara. Kesalahan kesepuluh ,Pengusaha yang hidup adalah yang memanipulasi PPNdan PPh, tetapi tidak diproses sesuai hukum, baik karena tidak diketahui aparat pajak, maupun karena menyuap Aparat Pajak. Kesalahan kesebelas adalah Pengusaha yang memanipulasi PPN, harus memanipulasi pula PPh dari laba perusahaan dan PPh karyawan. 
Tabel 5

\section{Simulasi Pilihan Manipulasi Toko Krupuk} Udang Sebagai Penjual

\begin{tabular}{|c|c|c|c|c|c|c|c|}
\hline ke Penjualan di SPT (\% dari aktual) & Aktual & $100 \%$ & $0 \%$ & $5 \%$ & $10 \%$ & $60 \%$ & $100 \%$ \\
\hline Status berdasarkan omset & & UUPPN & TdkNPWP & PKC & PKPM & PKPD & PKP P \\
\hline Sikap Pengusaha ter & & Taat & Sengaja & Terpaksa & Terpaksa & Terpaksa & Lebih \\
\hline & & & Tok taat & Tok taat & Tok taat & & dari Taa \\
\hline 1 Peniulalan per tahun (Juta Rp) & 10.000 & 10.000 & & 500 & 1.000 & 6.000 & 10.000 \\
\hline 2 Pembelian brg dagangan $(80 \%)$ & 8.000 & 8.000 & & 400 & 800 & 4.800 & 8.000 \\
\hline 3 Biaya ads, pm & 480 & 480 & & 24 & 48 & 288 & 480 \\
\hline 4 Gaij Karrawan $(5 \%)$ & 400 & 400 & & 20 & 40 & 240 & 400 \\
\hline 5 Laba Bersih sebelum Pajak $(9 \%)$ & 1.120 & 1.120 & & 56 & 112 & 672 & 1.120 \\
\hline 6 PPhbadan 25\% dari laba & & 280 & & 14 & 28 & 168 & 280 \\
\hline 7 PPh karyawan 1\% dibayar ka & & 4,0 & & 0,2 & 0,4 & 2,4 & 4,0 \\
\hline 8 PPN yang diterima negara & & 1.000 & & & 100 & 600 & 1.000 \\
\hline 9 PPN dibayar pembeli (Konsumen) & & 1.000 & & & 10 & 360 & \\
\hline 10 PPN dibayar peniual (TK Slameto) & & & & & 90 & 240 & 1.000 \\
\hline 11 PPh dan PPN dibayar peniulal & & 280 & & 14 & 118 & 408 & 1.80 \\
\hline 12 Laba bersih setelah PPh dan PPN & 1.120 & 840 & 1.120 & 1.106 & 1.002 & 712 & $(160)$ \\
\hline 13 Manipulasi PPN & & & 1.000 & 1.000 & 900 & 400 & \\
\hline 14 Manipulasi PPh laba perusahaan & & & 280 & 266 & 252 & 112 & \\
\hline 15 Manipulasi PF & & & 4,0 & 3,8 & 3,6 & 1,6 & \\
\hline 16 Jumlah manipulasi PPN \& PPh & & & 1.284 & 1.270 & 1.156 & 514 & \\
\hline \multicolumn{2}{|c|}{17 Denda teringan 200\% 1 th dan Penjara 2 thn } & & 2.568 & 2.540 & 2.311 & 1.027 & \\
\hline \multicolumn{2}{|c|}{18 Denda terberat $600 \%$ x 10 th dan Penjara 6 Th } & & 77.040 & 76.188 & 69.336 & 30.816 & \\
\hline \multicolumn{2}{|c|}{19 Harga yang dibayar Konsumenipembeli per kg } & 165 & 150 & 150 & 150 & 150 & 150 \\
\hline \multicolumn{2}{|c|}{20 Kesediaan KonsumenCusumer membeli } & Tidak & Beli & Beli & Beli & Beli & Beli \\
\hline Akibatyang diterima Toko Slameto & & Mati & Mati & Mati & Mati & Matil & Mati \\
\hline \multirow[t]{2}{*}{ Penvebab kematianbangknut } & & Ditinggal & Sanksi & Sanksi & Sanksi & Sanksi & Rugi \\
\hline & & Custumer & Denda & Denda & Denda & Denda & \\
\hline
\end{tabular}

\section{Menjadi pengusaha tanpa NPWP}

Pengusaha tanpa NPWP adalah pengusaha yang super jahat. Pengusaha tidak memiliki NPWP, sehingga tidak pernah membayar PPh, apalagi PPN.Pengusaha super jahat tidak melaporkan apapun ke kantor pelayanan pajak, akibatnya:

a. Tidak menyetor PPN, sehingga memanipulasi PPN 100\% atau Rp 1 milyar.

b. Tidak menyetor PPh laba perusahaan, sehingga memanipulasi PPh laba perusahaan Rp 280 juta.

c. Tidak menyetorkan PPh karyawan, sehingga memanipulasi PPh karyawan Rp 4 juta.

d. Total manipulasi PPN dan PPh Rp 1.284.000.000. e. Laba bersih setelah membayar PPN dan PPh Rp 1.120.000.000.

f. Jika penyelewengan ini diketahui tahun pertama, dan diproses secara hukum dan dikenai sanksi paling ringan, yaitu penjara 2 tahun dan denda 200\% dari pajak terutang senilai Rp2.568.000.000, pasti PT. Slameto bangkrut, karena laba 1.120.000.000 tidak cukup untuk membayar denda tersebut.

g. Jika penyelewengan diketahui setelah 10 tahun, dan diproses secara hukum dan dikenai sanksi paling berat, yaitu penjara 6 tahun dan denda $600 \%$ dari pajak terutang selama 10 tahun (sesuai waktu kadaluwarsa pajak) senilai Rp77 milyar, pasti PT. Slameto bangkrut, karena tidak mampu membayar denda.

\section{Menjadi PKC}

PKC adalah pengusaha yang terpaksa sangat jahat. Pengusaha memiliki NPWP, tetapi tidak menjadi PKP, yaitu melaporkan $5 \%$ dari penjualan sesengguhnya atau Rp 500 juta, sehingga termasuk PKC, akibatnya:

a. Tidak menyetor PPN sehingga memanipulasi PPN 100\% atau Rp 1 milyar.

b. Membayar PPh laba perusahaan Rp14 juta, kewajiban PPh seharusnya Rp 280 juta, memanipulasi PPh laba perusahaan Rp 266 juta.

c. Menyetorkan PPh karyawan hasil pemungutan dari karyawan Rp 200 ribu, seharusnya Rp 4 juta, memanipulasi PPh karyawan $\operatorname{Rp} 3,8$ juta.

d. Total manipulasi PPN dan PPh Rp 1.270.000.000.

e. Laba bersih setelah membayar PPN dan PPh Rp 1.106.000.000.

f. Jika penyelewengan ini diketahui tahun pertama, dan diproses secara hukum dan dikenai sanksi paling ringan, yaitu penjara 2 tahun dan denda 200\% dari pajak terutang senilai Rp2.540.000.000, pasti PT. Slameto bangkrut, karena laba 1.106.000.000 tidak cukup untuk membayar denda tersebut.

g. Jika penyelewengan diketahui setelah 10 tahun, dan diproses secara hukum dan dikenai sanksi paling berat, yaitu penjara 6 tahun dan denda $600 \%$ dari pajak terutang selama 10 tahun senilai Rp76 milyar, pasti PT. Slameto bangkrut, karena 
tidak mampu membayar denda.

h. Agar PT. Slameto dapat mempertahankan bisnisnya, maka dia harus melakukan negosiasi kalau terpaksa menyuap Aparat Pajak, agar manipulasi pajak yang dilakukan tidak diproses sesuai hukum. Hanggana (2008), menyimpulkan 30\% responden memilih menjadi PKC atau menjadi pengusaha yang terpaksa sangat jahat. Kesimpulan lainnya, 100\% pengusahan memilih melakukan negosiasi dan kalau terpaksa menyuap Aparat Pajak dibanding membayar denda paling ringan Rp 2,5 milyar sampai paling berat Rp76 milyar.

i. Sebagai toko penjual, sebenarnya PT. Slameto hanya sebagai wajib bayar PPh laba perusahaan $R p 280$ juta, tapi dia hanya membayar Rp 14 juta, sehingga disebut pengusaha yang terpaksa sangat jahat.

\section{Menjadi PKP Memanipulasi}

PKP $\mathrm{M}$ adalah pengusaha yang terpaksa jahat. PKP M memiliki NPWP dan menjadi PKP, tetapi memanipulasi PPN dan PPh, yaitu melaporkan $10 \%$ dari penjualan sebenarnya atau Rp 1 milyar, akibatnya:

a. Menyetor PPN ke Kantor Pajak Rp 100 juta yang berasal dari custumer 10\% senilai Rp 10 juta, dan dari uang sendiri 90\% senilai Rp 90 juta, karena gagal memungut dari custumer. Kewajiban PPN seharusnya Rp 1 milyar, sehingga memanipulasi PPN Rp 900 juta.

b. Membayar PPh laba perusahaan Rp28 juta, kewajiban PPh seharusnya Rp 280 juta, memanipulasi PPh laba perusahaan Rp 252 juta.

c. Menyetorkan PPh karyawan hasil pemungutan dari karyawan Rp 400 ribu, seharusnya Rp 4 juta, memanipulasi PPh karyawan $\mathrm{Rp} 3,6$ juta.

d. Total manipulasi PPN dan PPh Rp 1.156.000.000.

e. Laba bersih setelah membayar PPN dan PPh Rp 1.002.000.000.

f. Jika penyelewengan ini diketahui dan diproses secara hukum, maka dikenai sanksi penjara 2 sampai 6 tahun, dan denda Rp 2,3 milyar sampai Rp 69 milyar, pasti PT. Slmameto bangkrut.

g. Sebagi penjual, sebenarnya PT. Slameto hanya sebagai wajib bayar PPh laba perusahaan Rp 280 juta, tapi dia hanya membayar PPN Rp 100 juta dan PPh Rp28 juta, total Rp 128 juta masih lebih kecil dari kewajiban seharusnya Rp280 juta, sehingga disebut pengusaha yang terpaksa jahat.

\section{Menjadi PKP Dermawan}

PKP D adalah pengusaha yang terpaksa jahat tetapi berhati dermawan.PKP D memiliki NPWP dan menjadi PKP, memanipulasi PPN dan PPh, tetapi menyetor pajak lebih besar dari kewajiban pajak sesungguhnya, yaitu melaporkan $60 \%$ dari penjualan sesungguhnya atau Rp 6 milyar, akibatnya:

a. Menyetor PPN ke Kantor Pajak Rp 600 juta yang berasal dari custumer $60 \%$ senilai Rp 360 juta, dan dari uang sendiri $40 \%$ senilai $\mathrm{Rp} 240$ juta, karena gagal memungut dari custumer. Kewajiban PPN seharusnya Rp 1 milyar, sehingga memanipulasi PPN Rp 400 juta.

b. Membayar PPh laba perusahaan Rp168 juta, kewajiban PPh seharusnya Rp280 juta, memanipulasi PPh laba perusahaan Rp 112 juta.

c. Menyetorkan PPh karyawan hasil pemungutan dari karyawan Rp2,4 juta, seharusnya Rp 4 juta, memanipulasi $\mathrm{PPh}$ karyawan Rp 1,6 juta.

d. Total manipulasi PPN dan PPh Rp514.000.000.

e. Laba bersih setelah membayar PPN dan PPh Rp 712.000.000.

f. Jika penyelewengan ini diketahui dan diproses secara hukum, maka dikenai sanksi penjara 2 sampai 6 tahun, dan denda Rp 1 milyar sampai Rp 30 milyar, pasti PT. Slmaeto bangkrut.

g. Agar PT. Slameto dapat mempertahankan bisnisnya, maka dia harus melakukan negosiasi kalau terpaksa menyuap Aparat Pajak, agar manipulasi pajak yang dilakukan tidak diproses sesuai hukum. Hanggana (2008), menyimpulkan 67\% responden memilih menjadi PKP $M$ dan PKP D ini, yaitu menjadi PKP tetapi memanipulasi PPN dan PPh, hanya tidak diketahui berapa persen yang memilih PKP M dan berapa yang PKP D.

h. Sebagai toko penjual, sebenarnya PT. Slameto hanya sebagai wajib bayar PPh laba perusahaan Rp 280 juta, tapi dia sudah membayar PPN Rp 240 juta dan 
PPh Rp 168 juta, total Rp 408 juta, sudah melebihi kewajiban seharusnya Rp280 juta, sehingga disebut pengusaha yang terpaksa jahat berhati dermawan.

\section{Menjadi PKP Pahlawan}

PKP $P$ adalah pengusaha yang taat dan berhati pahlawan. PKP P memiliki NPWP dan menjadi PKP, dan tidak memanipulasi PPN dan $\mathrm{PPh}$, yaitu melaporkan $100 \%$ dari penjualan sesungguhnya, akibatnya:

a. Menyetor PPN Rp 1 milyar dari uang sendiri, karena gagal memungut dari custumer, sehingga tidak memanipulasi PPN.

b. Membayar PPh laba perusahaan Rp280 juta, sesuai kewajiban PPh seharusnya Rp 280 juta, tidak memanipulasi PPh laba.

c. Menyetorkan PPh karyawan hasil pemungutan dari karyawan Rp 4 juta, tidak memanipulasi PPh karyawan.

d. Rugi bersih setelah membayar PPN dan PPh Rp160 juta, dan bangkrut.

e. PT. Slameto hanya sebagai wajib bayar PPh laba perusahaan Rp 280 juta, tapi dia sudah membayar PPN dan PPh Rp 1,280 milyar. Dia disebut pengusaha yang taat dan berhati pahlawan, karena rela mati berkorban demi Negara.

\section{KESIMPULAN}

Kesalahan model pemungutan PPN:

1. Secara alamiah mendorong konsumen sebagai wajib bayar PPN tidak membayar PPN, karena harga lebih murah, tidak melanggar hukum, tidak ada sanksi, dan tersedia di lokasi yang sama.

2. Konsumen yang taat membayar PPN baik karena ketidakpahaman maupun keterpaksaan, tidak dapat mengawasi pengusaha, apakah uang PPN yang dititipkan ke pengusaha disetorkan ke negara atau tidak, karena tidak ada bukti.

3. Secara alamiah mendorong pengusaha tidak menjadi PKP, maka tidak dibebani kewajiban memungut PPN dari konsumen, maka dapat menjual dengan harga yang lebih murah, sehingga dapat memenangkan persaingan.

4. Mendzolimi Pengusaha, karena menjadikan Pengusaha wajib pungut PPN tanpa imbalan, tapi ada sanksi penjara dan denda.

5. Pengusaha membutuhkan modal kerja lebih besar untuk membayar PPN masukan.

6. Jika kondisi Pengusaha semua taat, maka munculnya Pengusaha Kecil dan Pengusaha
NPKP akan mematikan usaha Pengusaha yang taat. Kebangkrutan usaha ini disebabkan ditinggal konsumen, akibat harga lebih tinggi.

7. Pengusaha yang mentaati UU PPN bangkrut, karena ditinggal konsumen sebagai akibat harga jual yang lebih tinggi.

8. Jika kondisi Pengusaha banyak yang tidak taat, maka Pengusaha yang bertaubat ingin mentaati UU PPN akan bangkrut, akibat ditinggal konsumen, karena harga lebih tinggi.

9. Pengusaha yang memanipulasi PPN bangkrut jika diproses sesuai hukum, karena tidak mampu membayar denda dan dipenjara.

10. Pengusaha yang hidup adalah yang memanipulasi PPNdan PPh, tetapi tidak diproses sesuai hukum, baik karena tidak diketahui aparat pajak, maupun karena berkolusi atau menyuap Aparat Pajak.

11. Pengusaha yang memanipulasi PPN, harus memanipulasi pula PPh dari laba perusahaan dan PPh karyawan.

Kesalahan mekanisme pemungutan PPN sangat membahayakan keuangan negara. Untuk itu pemerintah harus segera merevisi mekanisme pemungutan PPN untuk mengatasi kesalahankesalahan tersebut sebelum pengusaha menyadari kalau mereka didzolimi.

\section{DAFTAR PUSTAKA}

Budget in brief APBN 2015. Pendapatan Negara 2015. Direktorat Jenderal Anggaran Kementerian Keuangan Republik Indonesia

Hanggana, Sri. 2008. Analisis Diskriptif Model Peraturan PPN Yang Menghambat dan yang Meningkatkan Motivasi Pengusaha Menyetor PPN. Manajemen Usahawan Indonesia. No.01/TH.XXXVII.Universitas Indonesia. Jakarta.

Hestu YS.2011. Jumlah Wajib Pajak dan PKP.http://www.pajak.go.id/,15 Apr 2012

Peraturan Menteri Keuangan Nomor 197/PMK.03/2013. Tentang Perubahan Atas Peraturan Menteri Keuangan Nomor 68/PMK.03/2010 Tentang Batasan Pengusaha Kecil Pajak Pertambahan Nilai.

UU Nomor 28 Tahun 2007. Tentang Perubahan Ketiga atas Undang-Undang Nomor 6 Tahun 1983 tentang Ketentuan Umum dan Tata Cara Perpajakan. 
UU Nomor 36 Tahun 2008. Tentang Perubahan keempat atas Undang-Undang Nomor 7 Tahun 1983 tentang Pajak Penghasilan.

UU Nomor 42 Tahun 2009. Tentang Perubahan Ketiga atas Undang-Undang Nomor 8 Tahun 1983 tentang Pajak Pertambahan Nilai Barang dan Jasa dan Pajak Penjualan atas Barang Mewah. 